УДК 72.012.8:725.39(045)

В. А. Зеленкова, асп.

\title{
НАЦІОНАЛЬНА СИМВОЛІКА ЯК ЕЛЕМЕНТ ПОЛІСЕМАНТИЧНОЇ СФЕРИ В ДИЗАЙНІ ІНТЕР'ЄРІВ АЕРОВОКЗАЛІВ
}

\author{
Національний авіаційний університет \\ E-mail: sampron@ukr.net
}

Розглянуто використання національної символіки як невід'ємного, полісемантичного елемента культури, в якому закодована інформація для певної групи людей. Показано, щуо національну символіку як елемент полісемантичної сфери застосовують в дизайні інтер'єрів аеровокзальних просторів.

Ключові слова: аеровокзали, аеропорти, дизайн, інтер'єр, символи.

\section{Постановка проблеми}

Зі зростанням попиту на авіаційні перевезення постає необхідність у реконструкції, будівництві та дизайні інтер'єрів аеропортів із використанням національної символіки. У зв'язку з цим виникає необхідність у дослідженні архітектури та дизайну в аеровокзальних комплексах крізь призму філософської галузі.

\section{Аналіз досліджень і публікацій}

Трактуванням символів у культурі в різні періоди займалися багато філософів та вчених.

Вивчення культурної символіки («прафеномени» Шпенглера, «архітипи» Юнга, «патос - формули» Варбурга) дозволить пояснити світ культури аналізом та синтезом - традиційними методами європейського раціонального знання [1].

Марксистська та немарксистська соціологія викриває культурну символіку як перетворювальну форму класових відносин.

У структуралізмі та семіотиці Московська - Тартуська школа намагалась знайти та описати стійкі закономірності виникнення суті знаками та знаковими системами.

На відміну від структуралізму та семіотики психоаналіз з'єднує символи та творчість культури від захисної трансформації руйнуючої енергії підсвідомого.
Символи в іконології (Варбург, Панофський) розширили мистецтвознавство до загальної науки про побудову та передачу культурного образу.

Герменевтика, онтологізуючи символ, переносить увагу не стільки на ньому, а скільки на нескінченний, проте законоподібний процес його інтерпретації.

Близький до герметичного тлумачення символа в культурі, але полемізуючий з нею $\epsilon$ діалогізм (Бахтін, Бубер, Розеншток - Хюсси) та трансцедентальний прагматизм (Апель), який робить акцент на непрозорості та нередуцийованості культурного символу, який отримує сенс та міжособисті комунікацiï.

Національна символіка нині мало досліджена.

У наукових працях висвітлюються загальнотехнічні, архітектурні, проектні, художні, історичні питання щодо аеропортів та аеровокзалів в галузі архітектури, реконструкції та будівництва.

У праці [2] В.А. Бабуров розглядає архітектуру Пекінського аеропорту.

У праці [3] І.О. Бєлінський, В.М. Золотоперий, М.В. Шинкарчук дають методичні рекомендації з архітектури аеропортів.

Ю. А. Попова зосереджувалася на архітектурній конструкції [4].

О.П. Олійник та В.А. Пилєва розглянули прийоми використання національної тематики в дизайні інтер'єрів аеропортів та аеровокзалів [5]. 
М. В. Комский розглядає прийоми поетапного розвитку аеровокзалів середньої пропускної спроможності та діапазону росту [6].

Н.В. Кожевін зосереджувався на архітектурних рішеннях та проектуванні аеропортів та споруд цивільної авіації [7].

А. Лепорк досліджував дизайн ітер'єрів закордонних аеропортів [8].

Мета роботи - дослідити застосування національної символіки в дизайні інтер'єрів аеропортів.

\section{Національні символи в культурі}

В епоху глобалізації та індустріалізації виникає необхідність звернутися до свого коріння, до витоків свого походження.

Одним із найсуттєвіших та діючих методів в дизайні інтер'єрів є застосування символів.

Символи - це найдавніші елементи спілкування між людьми, які виникли 3 зародженням стародавньої цивілізації, що трансформувалися та асимілювалась у культурі сучасного індустріального суспільства.

Символ (від грецького simbolon - знак, ознака) - умовне позначення предмета, поняття або явища [9], одне 3 центральних понять у філософії, естетики та філології. Без нього неможливо побудувати ні теорію мови, ні теорію пізнання.

Під символом мають на увазі художній образ, який умовно відтворює думку, ідею, почуття.

I.В. Гете писав, що в символі через окреме уявляють загальне - не як сон, не як тінь, але як живе миттєве одкровення того, що неможливо висловити [10].

Полісемантична система символів в індустріальній культурі посідає провідне місце.

У культурі символ $\epsilon$ полісемантичною (багатоплановою) системою передачі повідомлення 3 необмеженою кількістю значень. Це непряма форма, яка має фіксований сенс, але передбачає вільне трактування та заданість межі інтерпретації.
Культура в індустріальному суспільстві прийшла до певної межі в своєму утилітарному розвитку, тому виникає необхідність звернутися до свого національного коріння.

У зв'язку 3 цим 3 кінця ХХ - початку XIX ст. починає поступово відроджуватися застосування національних мотивів в оформленні громадських споруд. Це сприяло будівництву, реконструкції та дизайну аеровокзальних просторів застосування національних мотивів.

Архітектура аеропорту має великий вплив на людей. Цим визначається іiі ідеологічне значення, яке враховується при створенні архітектурних споруд. Таке значення виявляється не лише в її соціально-утилітарному, але й в художньо-естетичних та композиційних якостях.

Найголовніше методичне завдання національного стилю - вирішення естетичних проблем у дизайні інтер'єрів аеровокзалів, сприяючи легшому запам'ятовуванню та асоціюванню 3 державою, яка розвивається та поважає власні національно-образотворчі традиції.

Національний стиль - це зображення архітектурного та декоративно-прикладного мистецтва в національних особливостях культури певного регіону, які склалися протягом багатьох сторіч.

В архітектурі та дизайні, це унікальні форми, що були започатковані $з$ появою певної цивілізації та формувались із природних матеріалів.

Використання символів в аеровокзальних просторах проявляється в дизайні та архітектурі 3 застосуванням національних форм, кольорів, орнаментів, у малих формах архітектури, скульптури, оздоблювальних матеріалах.

Обов'язковим елементом у дизайні аеропортів $€$ наявність національних символів, які відіграють не останню роль у дизайні інтер'єрів аеровокзальних просторів та мають важливе смислове навантаження. 
Використання національних символів один із засобів акцентування національної особливості певного регіону, міста, країни.

Яскравим прикладом застосування національних символів в інтер'єрі та архітектурі аеровокзальних просторів є Денверський аеропорт у США, який відкрився у 1996 р. (автор проекту Кёртис Фентресс).

Національні символи починаються 3 в’їзду до Денверського аеропорту, де розташований монумент коня - Мустанга, який $\epsilon$ символом цього регіону, та закінчується дизайном підлоги в аеровокзалі.

Недалеко від Денверського терміналу розміщений монумент єгипетського бога Осиріса, бога загробного життя, що є символом смерті.

За формою гострокутні дахи немов із засніженими верхівками нагадують селище корінних жителів тієї країни, індійців - вігвам. Оскільки термінал аеропорту побудований на кладовищі індіанців, тому він має вигляд індіанських вігвамів.

План аеровокзалу має вигляд символічного знаку - свастики. Таке розташування злітно-посадкових смуг дають змогу для зручного керування трафіком літаків та дозволяе знизити залежність літаків від погоди.

Гармонійне поєднання зовнішньої форми аеровокзалу з внутрішньою формою, неначе знаходишся у великому вігвамі.

Малюнок на підлозі повторює дизайн стелі, що на тонкому рівні підтримує позитивну хвилю у пасажирів, які пересуваються по символічний, гранітній підлозі.

У багажному відділені терміналу розташоване зображення горгулії як символу оберегу.

Крім того, в аеровокзалі розміщено велику кількість тематичних фресок із зображенням корінних жителів.

Символи культури корінних індіанців розміщені в міжнародному аеропорту Ванкувер (Канада), який був побудований у 1968 р. та розширений у 1996 р. У ньому розташована одна 3 найбільш великих колекцій монументально-декоративного мистецтва тихоокеанського північно-західного прибережжя корінних індіанців.

Інтер'єр аеровокзального простору виконаний у блакитних та зелених кольорах, які символізують кольори землі та моря.

В аеровокзалі використано багато килимів та скла для передачі природного світла.

Велика кількість символів розташована в залі міжнародного прильоту.

Грандіозний водоспад із тотемною скульптурою розміщений над платформою, що з’єднує зону прильоту з головним терміналом пасажирів.

Водоспад потрапляє в річку (символ життя, відродження), фонтан, по якому пливе бронзова скульптура «Дух Хайда Гваіi, Нефритовое Каноє» - символ волі (скульптор Білл Рейд).

У терміналі аеровокзалу розміщено велику кількість дерев'яних тотемів та скульптур вуду.

Величезний тотем розміщений у відведеній для нього галереї аеровокзального комплексу, над яким розташовані декоративні панелі прямокутної форми блакитного кольору, що символізують душі померлих предків.

Дерев'яна, стилізована скульптура орла символ небесной (сонячної) сили, вогню та безсмерття - прикрашає залу, звідки можливо потрапити до зони реєстрації.

У середині залу аеровокзалу дві дерев'яні монументально-декоративні скульптури стоять із повернутими до неба долонями, ніби просять благословення у небес (богів).

Автор проекту міжнародного аеропорту Джакарта Сукарно-Хатта (Індонезія) французький архітектор Поль Андр'є зробив аеропорт у вигляді віяла, який є національним символом руху та щастя.

31985 р. аеропорт почав своє функціонування, але у 1992 та 2009 рр. були додатково відчинені другий та третій термінали.

По всій довжині дах аеровокзалу за формою схожий на віяло.

Біля пасажирських терміналів аеровокзалу розташовано монументальні скульптури національного божества Гаруди. 
Людина 3 крилами, дзьобом та нігтями є символом передачі божої мудрості людям та символом сонячної енергії.

Замість нескінченних коридорів та тунелів, замкнутого простору і замкнених дверей, властивих європейським аеропортам, термінал головного аеровокзалу має інтер'єр напіввідчиненої алеї.

Інтер'єр аеровокзального простору на другому поверсі зроблений у національному стилі 3 височенною стелею, великими люстрами, що підкреслюють національний колорит із використанням золотого, бірюзового, коричневого, чорного, червоного та білого національних кольорів.

Термінал зони вильоту аеровокзалу прикрашають національні маски, символічні орнаменти та декоративні розписи з зображенням індонезійських богів, які несуть у собі символічний характер, нагадуючи людям, що боги завжди поруч і спостерігають за ними.

Одна 3 характерних рис при оформленні релігійно-національних скульптур проявляється у тому, що кожну статую національного божества розміщено на клумбі з живих квітів як символ жертвування приношення для богів.

Відчинений перед відкриттям Олімпійських ігор 2008 р. у Пекіні аеропорт Бейджинг схожий на дракона, що символізує добробут.

Дах терміналу 3 зроблений із легких модульних конструкцій. Його зовнішня поверхня оболонки вкрита безліччю трикутних ліхтарів верхнього світла, що нагадують луску й підсилюють загальну подібність до образу дракону.

Термінал 3 вражає не тільки своїми розмірами, але й внутрішнім декором.

Скульптури національних міфічних істот (драконів), зроблених із міді та гіпсу, гармонійно поєдналися 3 гіперболізовано-стилізованими вазами та національно-релігійними хатками, що створюють цікаві прийоми в оформленні дизайну інтер'єру пасажирських зон терміналів.
Наприклад, гіпсове, скульптурне зображення китайського дракону виконує не тільки декоративну функцію, але й конструктивну у вигляді перегородки між приміщеннями - символ добробуту і достатку.

Прояв монументально-декоративних форми добре виражено в дизайні телефонних автоматів, що стилізовані під форми національних прапорів Китаю та гармонійно поєднуються з сучасними технологіями.

У міжнародному аеропорті Гонконгу Чек Лап Кок, побудованому Норманом Фостером в 1998 р., розміщені в національному стилі високі ліхтарні стовпи, які стилізовані під національний символ - пагоду.

Завдяки їхньому розташуванню на певній відстані одна від одної створюється національна атмосфера, незважаючи на те, що вони зроблені не $з$ традиційних матеріалів, а 3 заліза.

Територію аеровокзалу прикрашає декоративна скульптура, зроблена 3 міді та стилізована під форму дзвона.

\section{Висновки}

Символ - це невід'ємний, полісемантичний елемент культури, в якому закодована інформація, що відома певній групі людей.

Починаючи 3 античних часів символи використовують в інтер'єрах та в екстер'єрах громадських споруд.

Із розвитком індустріального суспільства символи застосовують у нових спорудах, зокрема в аеропортах.

Досліджено застосування національної символіки в дизайні інтер'єрів аеропортів на прикладах аеропортів США, Канади, Азіатських країн.

Показано, що національну символіку як елемент полісемантичної сфери застосовують у дизайні інтер'єрів аеровокзальних просторів.

Виявлено, що аеропорти безпосередньо стали символами країн. 


\section{Література}

1. Кузнецов В. Г. Женевская лингвистическая школа. От Соссюра к функционализму / В. Г. Кузнецов. - М.: Едиториал УРСС, 2003. - $184 \mathrm{c}$.

2. Бабуров В. Ворота Поднебесной / В. Бабуров // Архитектурный весник. - 2006. № 92. - С. 12-14.

3. Бєлінський I.O. Аеропорт / I.О. Бєлінський, В.М. Золотоперий, М.В. Шинкарчук // Енциклопедія Сучасної України. Т. 1. - К.: Укр. енцикл. ім. М. Бажана, 2001. - С. 206-207.

4. Попова Ю.А. Архитектура аэропортов / Ю.А. Попова // Эксперт. - 2007. - № 37. - С. 5-7.

5. Олійник О.П., Пилєва В.А. Прийоми використання національної тематики в дизайні інтер'єрів аеропортів та аеровокзалів / О.П. Олійник, В.А. Пилєва // Проблеми розвитку міського середовища: наук-техн. зб. К.: НАУ, 2009. - Вип.2. - С. 124-140.
6. Комский М.В. Архитектурно-строительные приемы этапного развития аэровокзалов / М.В. Комский // Трансп. стр-во. 1979. - №5. - 19-22 c.

7. Кожевин Н.В. Архитектура и проектирование аэропортов гражданской авиации / Н.В. Кожевин. - М., 1941. - 238 с.

8. Лепорк $A$. Новейшие аэропорты мира / А. Лепорк // Афиша-Мир. -2008. - №24. C. 3-5.

9. Культурология. ХХ век. Энциклопедия. - СПб.: Университетская книга, 1998. - 365 c.

10. Гегель. Лекции по эстетике. Кн. первая / Гегель / пер. В.Г. Столпнера // Соч. T. XIV. - М.: Гос. социально-эконом. изд-во., 1938. - 494 с.

Стаття надійшла до редакції 20.10.2011. 